\title{
Institutions, policies, and arguments: context and strategy in EU policy framing
}

\begin{abstract}
Studies of framing in the EU political system are still a rarity and they suffer from a lack of systematic empirical analysis. Addressing this gap, we ask if institutional and policy contexts intertwined with the strategic side of framing can explain the number and types of frames employed by different stakeholders. We draw on framing theory, policy analysis and a conception of the European Union as a multilevel system to develop our arguments about the impact of contexts and strategy on the framing dynamics in EU financial market regulation and environmental policy. We use a computer assisted manual content analysis and develop a fourfold typology of frames to study the frames that were prevalent in the debates on four EU policy proposals at the EU level and in Germany, Sweden, the Netherlands and the United Kingdom. The main empirical finding is that both contexts and strategies exert a significant impact on the number and types of frames in EU policy debates. In conceptual terms, the article contributes to developing more fine-grained tools for studying frames and their underlying dimensions.
\end{abstract}

Key words: framing, context, strategic action, interest groups, EU multilevel political system 
Framing theory suggests that since every policy issue has multiple potential dimensions, framing - selecting and emphasizing particular aspects of an issue - is an important tool for policy actors (Daviter 2009; Baumgartner and Mahoney 2008). Through framing, policy actors can play a crucial independent role in public policy debates and impact on their outcomes (Baumgartner and Jones 1993). While commonly accepted in American political science, this phenomenon is still under-researched in EU studies (exceptions are Daviter 2009; Klüver, Mahoney, Opper 2015). We know rather little about the emergence and variation of frames in the EU, especially with regard to the contextual factors that impact on these frames. The lack is surprising in two respects. On the one hand, the argumentative turn in policy analysis highlighted the centrality of arguments - and therefore frames - 'in all stages of the policy process' (Majone 1989: 1). On the other hand, scholars rooted in different schools of thought agree that the institutional contexts of political systems filter the arguments, problems and solutions that find entry into the political process (see for example: Schattschneider 1960: 30).

Why can European Union (EU) studies in particular benefit from a framing perspective? The EU policymaking system is characterised by contested competencies and competing constituencies. It is frequently difficult to predict how key actors will align on a given issue and which cleavages will matter most in determining outcomes (Peterson 2001). In this context, frames do not only help to make sense of 'amorphous, ill-defined problematic situation[s]' (Dudley/Richardson 1999: 226), but are also at the centre of the political conflict because they can 'empower certain actors over other actors' (Harcourt 1998: 370). Studying framing can therefore improve the accounts of EU policy processes and outcomes (see also Daviter 2011). 
In this study, we focus on what we label 'essential frames' in EU policymaking. These capture what the actors involved in an EU policy debate perceive to be the essential elements in the EU's policy proposals. We contend that focusing on the types and numbers of essential frames yields important insights into EU policy-making. Highlighting the different types of essential frames sheds lights on what EU policies are actually about. Focusing on the number of essential frames illuminates the complexity of the policy problem, the magnitude of the conflict and the potential shifts of attention during the policy debate. Addressing the research gap on contextual factors that influence the emergence and variation of frames in the EU, we focus on two contextual factors: (1) the institutional context and (2) the policy context. However, taking account of the insight that public policies emerge from the strategic interaction of policy actors (see Scharpf 1997: 11), we pay also attention to the strategic element in framing processes and explore if (3) the strategic highlighting of major policy aspects impacts on the types and numbers of essential frames in EU policy debates.

In our empirical analysis, we classify the identified essential frames along two dimensions. On the one hand, we distinguish among generic and specific frames (see de Vreese 2005). On the other hand, we separate institutional from policy frames to analyse the impact of the contextual factors. We study these frames in the debates on four EU policy proposals which were initiated between 2008 and 2010. We focus on two environmental policy debates and two instances of financial market regulation. Our research design includes not only variation across and within policy areas, but also across the EU and the national levels as well as across four member states (Germany, the Netherlands, Sweden, and the United Kingdom).

Our contribution to the debate is not only in the focus on different types of essential frames and in disentangling contextual effects from strategic action, but also in the methodological approach to the study of policy frames. Till now the majority of research on frames in public policymaking was conducted through case studies based on interviews or document analyses 
(see for example: Baumgartner and Jones 1993; Daviter 2009). A new trend of research uses a quantitative approach, focused on word scores and cluster analysis (see for example: Klüver, Mahoney and Opper 2015). We combine both qualitative and quantitative approaches. The basis of our study is a computer assisted manual content analysis (for details see: Boräng et al 2014) that was conducted on a sample of policy documents. The codes obtained from the content analysis were then transformed into numerical data to perform comparative statistical analyses on them.

The article proceeds as follows. In the next section, we illustrate our theoretical framework and develop the hypotheses that guide the empirical analysis. Afterwards, we explain our research design, followed by a presentation of the empirical analysis. First, we present the fourfold typology of frames that highlights which essential frames emerged in the four policy debates and demonstrates their correspondence with the EU's institutional characteristics and the two policy areas. Secondly, we present statistical models that seek to account for the number and types of frames in each debate. We conclude with a summary of our results and a discussion of the broader implications of our findings.

\section{The emergence and variation of frames in the EU multilevel system}

Frames can relate to different aspects of policy proposals. In our study, we identify through document analyses what the actors participating in EU policy debates perceive to be the essence of the European Commission's directive proposals (see also Boräng et al. 2014). These frames are likely to impact on the positions of the actors as well as the policy outcomes because they denote what 'actors perceive to be at stake' in these proposals (Daviter 2009: 1118). We subdivide these essential frames in four different types along two dimensions. First, drawing on previous framing studies, we distinguish among generic and specific frames. Whereas specific frames are tied to the political issue at hand, generic frames can be applied across policy areas, some even over time and, potentially in different cultural contexts (de 
Vreese 2005). The former capture issue specific aspects of frame selection, organization, and elaboration while the latter offer less possibility for examining the framing of an event in great detail, but facilitate comparisons of framing practices between issues and countries (de Vreese 2005: 109). Incorporating both specific and generic frames in our analysis serves to improve our understanding of the common themes and the more specific aspects of EU policy debates. Secondly, to increase our knowledge about the filtering effects of political institutions and policy areas, we distinguish institutional frames that are derived from the institutional setting and relate to the general rules of the EU political system from policy frames that relate to substantial policy goals, norms, and instruments, thus leading to a fourfold classification scheme of generic institutional frames, specific institutional frames, generic policy frames, and specific policy frames. Given our interest in the impact of the institutional and policy contexts, these merit a more detailed discussion before we move on to framing strategies and the role of strategic action.

\subsection{Institutional context - the EU as a multilevel governance system}

There exists a widely shared system of rules and procedures in the European Union's political system that defines who the actors are, how they make sense of each other's actions, and what types of actions are possible (Stone Sweet et al. 2001: 12). These institutions embody a set of 'normative and cognitive structures' (Surel 2000: 509), and they include a number of public policies and a wide repertoire of policy instruments. An important element of this institutional setting is the strong focus on the creation, maintenance, and policing of the internal market through regulatory policies (Majone 1996). We argue that this institutional context filters the frames that emerge in EU legislation, promoting the emergence of frames related to market integration, regulation and policy harmonization while being for example less permeable to redistributive frames. These institutional frames matter in most EU policy areas even if their relevance may vary across policy proposals. We term those generic institutional frames, 
which relate to the general rule system of the EU political system and those specific institutional frames that refer to more detailed rules such as specific regulatory instruments.

Conceptualising the European Union as multilevel system generates the expectation that actors at different levels will engage in framing and that the actors' frames will differ depending on the level on which actors are situated as well as across national sub-units in this system. We expect that generic institutional frames will be mostly used at the European level. At that level, the multilevel character of the EU enforces a large dose of cooperation and coordination between stakeholders (Marks 1993: 402). Here, the need for policy entrepreneurs who take skilled action to construct or revise frames is extremely high. Authors agree that this crucial role is often played by the European Commission (Stone Sweet et al. 2001; Daviter 2009). Frequently, the Commission frames policy proposals in a way that is meant to bring together the relevant political and societal actors as well as decrease the amount of conflict between them. As default these frames have to be more generic than specific. Departing from the assumption that a variety of policy advocates engages in a framing competition to shape EU legislation, we suggest that other EU level actors such as the European Parliament or EU level interest groups must also take account of the high consensus requirements in the EU political system if the policy status quo is to be changed. Thus, they also will employ generic institutional frames.

In contrast, the stance of national actors on EU policy proposals depends much more on national interests and the degree to which already existing national regulation would have to be adjusted to new EU regulation (Green Cowles et al. 2001: 12-14). Major institutional characteristics of the EU member states vary in important ways: their varieties of capitalism in terms of coordinated and liberal market economies (Hall and Soskice 2001), their welfare states in the form of liberal, corporatist, and social-democratic welfare regimes (EspingAndersen 1990) and their patterns of interest mediation in the corporatist and pluralistic 
modes (Lijphart 2012). Accordingly, their national borders should promote different problem views and a rivalry over policy solutions which need to be accommodated in EU policymaking. Taking in consideration the variety of national circumstances, it is not a far leap to expect that actors from different member states will invoke different frames when responding to EU policy proposals. In sum, we derive the following conjectures from the EU's institutional multilevel- context:

Hypothesis 1.1: EU level actors employ fewer frames than national actors. Hypothesis 1.2: EU level actors employ generic institutional frames more frequently than the national actors.

Hypothesis 1.3: The number and the types of frames invoked vary across EU member states.

\subsection{Policy context}

Drawing on policy studies leads to the expectation that we will identify generic policy frames that matter across policy areas such as frames about market integration or consumer safety, but also frames that relate specifically to environmental policies, to financial market policies, to education policies, etc. (specific policy frames). The high degree of functional segmentation both in the EU institutions and in the member states' political systems is likely to contribute to the emergence of specific policy frames, because the actors in different policy sub-systems develop their own rationality criteria over time. Nonetheless, according to the logic of the EU multilevel setting, we anticipate that national actors invoke more specific policy frames in order to defend or elaborate their specific national policy settings than the EU level actors which tend to rely to a greater extent on generic policy frames to work towards a consensus among the involved stakeholders or organizational members.

Another important insight from the policy studies is the distinction between policy areas that operate, by and large, in a routine mode of policy-making or within widely accepted policy trajectories and policy areas that are in a state of or in the aftermath of a crisis. Many policy studies suggest that external shocks and crisis situations can challenge prevailing policy 
principles and instruments, forming windows of opportunity and giving rise to paradigm shifts (for a useful discussion, see Surel 2000). Bojn et al. (2009: 82) suggest that 'the aftermath of a crisis and its outcomes can be usefully understood in terms of "frame contests" between the various actors that seek to exploit this crisis-induced opportunity space (...). Crisis typically generates a contest between frames and counter-frames concerning the nature and severity of a crisis, its causes, the responsibility for its occurrence, or escalation, and implications for the future'.

To gauge the relevance of policy areas for framing activities, we analyse two policy proposals in the area of financial market policy and two proposals in the area of environmental policy. Financial market regulation presently undergoes a paradigm shift towards a more detailed, stricter and comprehensive regulation that is meant to strengthen the stability of financial markets and the protection of consumers and investors. This shift was triggered by the Global Financial Crisis in 2007 and meets, in part, with strong national opposition. In comparison, EU environmental policymaking is well established and its evolution towards stricter standards for climate protection is connected to that of international environmental policy regimes. Even though specific policy decisions may be contested, the broad trajectory of EU environmental policy is widely accepted. Today's measures focus more on setting substantial goals rather than on prescribing strict policy instruments thus allowing for more flexibility for the addressees. We thus expect that:

Hypothesis 2.1: EU level actors employ specific policy frames less frequently than national actors.

Hypothesis 2.2: EU level actors employ generic policy frames more frequently than national actors.

Hypothesis 2.3: Financial market regulation is marked by a larger number and a greater variety of frames than environmental policy.

\subsection{Strategic action}


Next to institutional and policy context, the number and types of frames can be also dependent on the strategic choices of actors. The institutional and the policy contexts do not fully determine what aspects of EU policy proposals actors highlight. Policy actors are neither merely acting out contextually defined scripts nor are they 'rule-following automata' (Scharpf 1997: 11, 21). Entman's influential definition of framing also emphasizes the intentional side of framing processes: 'To frame is to select some aspects of a perceived reality and make them more salient in a communicating text...' (Entman 1993: 52, our emphasis).

Conceiving of framing as purposeful action within the boundaries of contextual settings has important implications. Given this assumption, the amount of actors that become vocal in a policy debate cannot be taken as a structural given but is the outcome of these actors' calculations to engage in that debate. Considering that each actor is specifically located within the EU's institutional and policy context yields the expectation that the number of frames tends to increase with the number of actors that become vocal on a policy proposal. This proposition modifies the expectation (see Schattschneider 1960: 16-17) that actors employ frames to widen the scope of the conflicts. In contrast, we claim that efforts at framing or reframing EU policy proposals aim not so much at increasing the number of participants in the policy debates, but at putting into question the scope, validity, or legitimacy of others' arguments. Due to the lack of a European public, strategic framing is usually not aimed at bringing larger publics into EU legislative processes but at shifting the debate. A testable implication of this proposition is that a greater number of actors in EU policy debates is associated with a rising number of frames in these debates. In contrast, the number of frames need not increase if framing is mostly aimed at widening the scope of conflicts: One frame may be enough to appeal to a broad public.

To deepen our analysis of the strategic element in framing processes, we draw further on Entman's (1993: 52) definition of frames. He suggests that frames serve four purposes: they 
promote a particular definition, causal diagnosis, moral evaluation, and/or treatment recommendation of a problem. Evidently, all four aspects can be related to what the policy actors believe to be essential in EU policy proposals and therefore increase the number of frames. In order to explore to what extent actors highlight these aspects and how they are related to the actors' essential frames, we operationalize them as follows: First, we expect that actors will put forward expert evidence as well as arguments about the urgency of the policy proposal when defining the underlying problem, suggesting either that this merits the proposed EU activities or that it does not. We anticipate that arguments defining the problem are associated with the usage of institutional frames that highlight the EU's capacity and its legitimacy to take action, be they specific or generic. Secondly, with regard to the causal analysis of the underlying problem and the proposed solutions, it is likely that policy advocates put forward arguments about how their interests are connected to the policy proposals. We anticipate that this causal analysis connects policy frames, be they generic or specific, with the actors' interests. Thirdly, the actors' moral judgements are embodied in normative arguments about the EU policy proposals. These moral arguments can be associated with an increased usage of both policy and institutional frames that relate to the general EU rule system or to more specific policy principles and norms. Fourthly, many actors will single out the remedial capacity of the policy proposals in terms of their social welfare effects or the burdens they might impose. These remedial arguments should be associated with a greater usage of specific policy frames. Given the tentative character of the preceding discussion, we make the following three general propositions about the impact of actor density and the strategic highlighting of policy aspects on the one hand, and essential frames, on the other:

Hypothesis 3.1: The more actors are involved in a policy debate, the greater is the number of frames and the more types of frames are invoked. 
Hypothesis 3.2: The number of frames in a public policy debate increases with each highlighted policy aspect (problem definition, causal aspect, moral aspect, remedial aspect).

Hypothesis 3.3: The policy aspects are connected in different ways with the four types of frames in the policy debates.

\section{Research design}

We test these hypotheses in a comparative study of four EU policy debates at the EU level and in four EU member states, namely Germany, the Netherlands, Sweden, and the United Kingdom. This selection of countries controls important national characteristics but assures also reasonable variation with respect to country size, duration of EU membership, varieties of welfare state and capitalism, and the state-interest group model (see Hall and Soskice 2001; Lijphart 2012; Esping-Andersen 1990). Given that earlier studies identified a substantial impact of such structural differences on policy preferences in EU politics (see Ringe 2005), we expect to observe different types and numbers of frames across the four countries.

As part of the larger INTEREURO project on interest group politics (for further information, see Beyers et al. 2014), we selected the four policy proposals in our study based on the following criteria. Of all European Commission directives that were introduced between 2008 and 2010, we identified 20 policy proposals which were mentioned in at least one of two European level media source (Agence Europe, European Voice) and two of three national level outlets (Financial Times, Le Monde, or Frankfurter Allgemeine Zeitung) to ensure the presence of both EU level and national level policy debates.

Our two financial market directive proposals are: the directive proposals on alternative investment fund managers (AIFM - European Commission 2009) and deposit guarantee schemes (DGS - European Commission 2010). The former aimed at harmonizing the requirements for entities engaged in the management and administration of alternative investment funds. It was proposed in June 2009 and passed the EU's legislature one year later. 
The latter was introduced in 2010 to revise earlier legislation on this subject. It was meant to protect savers and to prevent bank runs in case of a bank's bankruptcy as well as to harmonize national deposit protection schemes. The European Parliament passed the directive in April 2014, based on an agreement that was reached in the trilogue with the Commission and the EU Council in December 2013.

The two environmental cases are part of the EU energy and climate package. They focus on the disposal of electrical and electronic waste (WEEE - European Commission 2008a) and on the promotion of the use of renewable energy resources (RED - European Commission 2008b). The RED directive proposal aimed at establishing an overall binding target of $20 \%$ share of renewable energy sources in energy consumption and of $10 \%$ for the use of biofuels in transport to be achieved by each member state by 2020 . The directive was proposed in January 2008 and passed the EU's legislative process in June 2012. The WEEE proposal was introduced to revise an earlier directive from 2003, addressing mostly the administrative problems and costs caused by that directive. The recast proposal was tabled in December 2008 and passed in July 2012.

To study the frames, we relied on a computer assisted qualitative content analysis (supported by the software MAXQDA). This method has the advantage that it can be applied to documents in different languages and allows the study not only of the manifest meanings and frequencies of words, but also of their latent and contextual meanings (e.g. Schreier 2012). Six coders analysed the content of the policy documents. Krippendorff's alpha for inter-coder reliability was 0.739 , with an $87.44 \%$ agreement.

We developed a comprehensive codebook consisting of a series of questions to focus on while analysing the policy documents to study the actors' frames. Given the function of frames to reduce complexity, we identify what the authors of the documents perceived to be the essence of the EU directive proposals. To identify these frames, the coders marked those passages in 
the selected texts which indicated: 'What the author of the text thinks is at stake in this proposal at a more general level?' After identifying these passages, we categorized the coded frames on the one hand as generic or specific frames, and on the other hand as institutional or policy frames. Furthermore, we transformed the identified codings into numerical data to facilitate the systematic comparison of these frames across policy proposals.

The total number of essential frames and the sums of the different types of essential frames invoked in the policy debates are our dependent variables. Our explanatory variables are also derived from the coded documents and actors. They cover the location of the actors in the EU multilevel system (EU level or national level), the policy context (financial or environmental policy), the density of interest groups that mobilized on each policy proposal, and the strategic highlighting of the four policy dimensions. These variables have been coded independently from the 'essential' frames and are described in table 1. Furthermore, we include control variables for the extent of change a policy proposal is perceived to bring about (routine change or major change), the policy position an actor assumed (in favour or against a proposal), and the type of actor who voiced the frame (public interest group, business interest group, EU actors, state actors, institution, or firm).

\section{TABLE 1 ABOUT HERE}

\section{Empirical analysis}

\subsection{Descriptive evidence}

Using the EU level and the national governments' and parliaments' databases, media and web mining, we identified the public and private stakeholders that were involved in the four policy debates. In total, we collected 704 documents from 443 actors. Based on the populations of actors involved in the four policy debates, the number of documents in each debate, and the 
positions the actors held, we drew a stratified sample of documents for the content analysis. This procedure resulted in a sample of 278 documents written by 307 actors, among them 76 German actors, 73 Dutch actors, 42 Swedish actors, 67 British actors, and 49 EU level actors. 266 actors presented one policy document, and 41 actors tabled 15 joint position papers. Among these 41 actors were 25 Dutch groups, 11 German organizations, and 5 British groups. About $79 \%$ of the documents are position papers drawn up by interest groups, think tanks and companies, the rest being government studies, expert reports, etc.

In this sample, $60 \%$, or 184 out of the 307 policy actors mention an essential frame of the proposal. 36 of these used three to six frames, 46 referred to two frames, and 102 mentioned just one frame. The bulk of the actors mentioning more than two frames were involved in the two financial market proposals: 27 relative to nine such actors in EU environmental policy.

Table 2 lists the distribution of frames across the four policy debates. In total, we identified 14 essential frames in these debates. In the debate on the WEEE directive, seven frames mattered, in the debates on the RED and the DGS directives we identified eight frames, and in the debate on the AIFM directive nine frames played a role. This is not only preliminary evidence that EU policy proposals address complex problems, but also that EU policy debates are framing competitions in which actors seek to steer policy debates in their preferred direction. As suggested, generic institutional frames play an important role in both EU policy areas. They are the most common type of essential frame in the four debates and have been used 136 times, underlining that the EU's rule system weighs heavily on the types of frames that emerge in EU policy debates. Frames related to EU regulation and harmonization as well as the administrative (and economic) burdens attributed to the EU policies emerged in all four policy debates. The frames on the implementation of EU policies and on information and transparency were also important in both policy areas, but not in all four policy debates. As a 
highly specific institutional frame, the setting of mandatory targets was used only in one proposal (for the promotion of renewable energies) and played here a major role.

Policy frames were more confined in their scope than the institutional frames. Generic policy frames were mentioned only 53 times. And of these frames, only market integration was highlighted in both policy areas. Both the health and the employment frames mattered in just one policy debate, and the consumer safety frame was invoked in just one policy area and two policy debates. In contrast to our expectations, generic policy frames seem to contribute to substantial differences among the policy areas. Specific policy frames were used more frequently (97 times) and could be identified in both policy areas: Financial market stability played an important role in the debates on the AIFM and the DGS directive proposals. The environment frame guided the debates on the WEEE and the RED directive proposals while the climate and the energy frame mattered only in the latter. In sum, generic institutional frames have a unifying effect in terms of EU policy debates, while, apart from the market integration frame, both generic and specific policy frames contribute to their diversity.

\section{TABLE 2 ABOUT HERE}

\subsection{Accounting for the number and types of frames in EU policy debates}

We analyse the impact of the explanatory variables by means of Poisson regressions in four models, because we have four dependent variables: (1) the total number of frames invoked by an actor, (2) the number of generic institutional frames, (3) the number of generic policy frames, and (4) the number of specific policy frames invoked by an actor. ${ }^{1}$ These are count variables that are not overly dispersed. The top panel in table 3 presents the regression results. Raw coefficients are Poisson regression coefficients. The figures in brackets are standard errors. The significance levels are based on two-tailed tests. The bottom panel presents the

\footnotetext{
${ }^{1}$ We did not calculate a model for the specific institutional frame 'mandatory targets' because it was invoked by only a very small number of actors in the RED case and because it is a binary variable.
} 
summary statistics of the maximum likelihood estimations. All models are statistically significant, and it appears that the model explaining the extent of generic policy frames works better than the models accounting for the overall number of frames and the other types of frames.

\section{TABLE 3 ABOUT HERE}

The evidence presented in table 3 indicates the major characteristics of the framing patterns in the EU policy debates. First, the framing patterns of European and national actors display important commonalities. In contrast to hypotheses 1.2 and 2.2., EU level actors do neither resort to generic institutional frames nor to generic policy frames in any other way than national actors. Note also that the national actors do not differ in their use of generic institutional frames. As they are part of the common mode of thinking and common language in EU policymaking, it is common for all actors to employ generic institutional frames in EU policy debates. National policy advocates are no exception to this pattern. Hence, a substantial portion of the frames that actors invoke in EU policymaking are shaped by the EU's institutional terms of debate.

Beyond these common characteristics, the multilevel institutional context triggers important cross-level and cross-national differences. EU level actors employ a smaller number of frames than those national actors that form the reference category (Swedish actors) which supports hypothesis 1.1. As expected in hypothesis 2.1., EU level actors engage also fewer specific policy frames than national actors. Being located at the apex of national political or associational systems, EU level actors tend to bridge national heterogeneity and aggregate the disparate policy frames of their members. Their interest aggregation function lets them highlight fewer frames than the national actors who voice their positions based on their domestic institutional and policy contexts and the interactions in EU policy-making. Through 
the use of specific policy frames, national actors draw attention to their domestic policy settings.

Furthermore, the national contexts prompt important cross-national differences, as we expected in hypothesis 1.3. British and German policy actors invoke fewer frames than Swedish actors, and British and Dutch policy advocates use fewer generic policy frames than Swedish actors. All in all then, the cross-national differences apply to just one type of frame (generic policy frames) and to the overall number of frames that national actors invoke. Note also that there is no clear-cut connection between the national institutional characteristics (modes of interest mediation, welfare state regimes, and varieties of capitalism) and the essential frames that the national actors employed in the four policy debates. Either these characteristics do not matter (at least not in the areas of financial market regulation and environmental policy), and are more limited in scope than is frequently claimed, or the differences across the institutional sectors within these countries counteract each other.

The policy context proves highly influential for the frames employed in EU policy-making. The general characteristics of policy areas impact decisively on these frames. The actors in EU environmental policymaking invoke fewer frames, in particular fewer generic policy frames, than the actors in EU financial market regulation which is evidence in favour of hypothesis 2.3 . We attribute these differences to different policy origins and trajectories. The reregulation of financial markets has a major exogenous policy origin: the global financial crisis has opened up new courses of action and put into question established policy paradigms. EU environmental policy has more gradually evolved since the 1980 s and not been subject to such a paradigm change in recent years.

Finally, as expected, the strategic decisions of actors leave an imprint on the frame types and numbers. Taking into account framing strategies on top of institutional and policy context clearly helps accounting for EU framing dynamics. First, interest group density leaves its 
mark on the nature of political debates even though not as uniformly as we envisaged. The more actors decide to engage in a policy debate, the more frames are invoked which supports hypothesis 3.1. Note also that the more actors are involved, the more policy oriented the debate becomes, both in terms of generic and specific policy frames. Correspondingly, the denser the actor population, the fewer references do the actors make to the generic institutional aspects of the EU political system.

Next, hypothesis 3.2 about the association between the different policy aspects and the number of essential frames in the policy debates finds empirical support. The strategic highlighting of a major aspect of a policy proposal raises the number of essential frames. Furthermore, as expected, the four policy aspects bear differently on the four types of essential frames that we distinguish (hypothesis 3.3). Two aspects have a rather narrow scope in that respect. Highlighting the remedial aspect of EU policies is a proposal-specific framing strategy that increases only the number of specific policy frames. Emphasizing the problem definition is associated with an increased usage of generic institutional frames. The other two aspects have a broader scope. Arguments about the causal aspect of EU policies are associated with an increased use of both generic and specific policy frames, but are not linked to the usage of institutional frames. Finally, actors highlighting the moral dimension of EU policy proposals invoke both specific policy frames and generic institutional frames. In sum, only one of the four aspects is associated with an increased usage of both policy and institutional frames (moral aspects). Highlighting other policy aspects increases the density of either institutional frames (problem definition) or policy frames (remedial and causal aspects). More generally, policy advocates emphasize those policy aspects that are related to what they perceive to be essential in EU policymaking in order to impact on the outcome of EU legislation.

\section{Conclusions}


This article studies the effect of contextual factors and of the strategic highlighting of different policy aspects on the types and number of essential frames that have emerged in four EU policy debates. We distinguished among four types of essential frames: generic institutional frames, generic policy frames, specific institutional frames, and specific policy frames. Our results indicate that the EU's institutional and policy contexts exert a significant impact on the invoked frames. The EU's institutional context gives rise to the most common type of frame in EU politics, namely generic institutional frames about EU regulation or harmonization. The policy context gives rise to the second most common type of frame: specific policy frames are often invoked by national actors that point to their national policy settings. Furthermore, policy areas in the aftermath of a crisis such as financial market regulation experience more intense frame contests than those in which policy-makers operate in a less turbulent policy context such as environmental policy.

The article also highlights the strategic component of framing. Policy advocates are not forced by the institutional and policy contexts to employ certain frames; they can, at least in part, select which policy aspect they highlight. However, their discretion to highlight different policy aspects varies with what they find to be essential in EU policymaking as our empirical analysis has shown. Actors subscribing to generic institutional frames would draw attention to the definition of the policy problem as well as the moral aspects of the policy proposal. Generic policy frames limit the argumentative space even more: they are mostly a vehicle for arguments about the causes and effects of the proposed policies in connection with constituency interests. Specific policy frames have the broadest dimensionality; actors point out normative, causal, or remedial policy aspects when invoking this type of frame. Relating the four frame types systematically to different policy aspects is meant to be a first step in the development of a more fine grained analysis of frames and their underlying dimensions as they are invoked in public policymaking. 
Finally, we demonstrate that the more actors become involved in the policy debates, the more the frame competition intensifies. In the EU's contested policy space, it is difficult for individual actors to win the day with their frames. Framing is likely to lead to counter-framing and particularly to a greater variety of specific policy frames because these lend themselves to emphasizing various aspects of EU policy proposals. Hence, the outcome of such a conflict expansion is rather uncertain.

Word count: 6,669 (title, text and references) $+1,425($ tables, $3 * 475)=8,094$ 


\section{References}

Baumgartner, F. R. and Jones, B. D. (1993) Agendas and Instability in American Politics, Chicago: University of Chicago Press.

Baumgartner, F. R., and Mahoney, C. (2008) 'The two faces of framing - Individual-level framing and collective issue definition in the European Union.' European Union Politics 9(3): 435-449.

Beyers, J., Bonafont, L. Chaques, Dür, A. Eising, R., Fink-Hafner, D. Lowery, D., Mahoney, C., Maloney, W., and Naurin, D. (2014) 'The INTEREURO Project: Logic and structure', Interest Groups and Advocacy 3(2): 126-140.

Bojn, A., 't Hart, P. and McConnell, A. (2009) 'Crisis exploitation: political and policy impacts of framing contests', Journal of European Public Policy 16(1): 81-106.

Boräng, F., Eising, R., Klüver, H., Mahoney, Ch., Naurin, D., Rasch, D, Rozbicka, P. (2014) 'Measuring frames: A comparison of methodological alternatives', Interest Groups and Advocacy 3 ( 2): 188-201

Daviter, F. (2009) 'Schattschneider in Brussels: How Policy Conflict Reshaped the Biotechnology Agenda in the European Union', West European Politics 32(6): 1118-1139.

Daviter, F. (2011) Policy Framing in the European Union, Palgrave Macmillan.

De Vreese, C. (2005) 'News framing: Theory and typology', Information Design Journal \& Document, Design 13(1): 51-62.

Dudley, G, and J. Richardson (1999) 'Competing advocacy coalitions and the process of 'frame reflection': a longitudinal analysis of EU steel policy', Journal of European Public Policy 6(2): 225-248.

Entman, R. (1993) 'Framing: Toward Clarification of a Fractured Paradigm', Journal of Communication 43(4): 51-58.

Esping-Andersen, G. (1990) The Three Worlds of Welfare Capitalism, Princeton: Princeton University Press.

European Commission (2008a) Proposal for a Directive of the European Parliament and of the Council on waste electrical and electronic equipment (WEEE) (Recast), COM (2008) 810.

European Commission (2008b) Proposal for a Directive of the European Parliament and of the Council on the promotion of the use of energy from renewable sources, COM (2008) 019.

European Commission (2009) Proposal for a Directive of the European Parliament and of the Council on Alternative Investment Fund Managers and amending Directives 2004/39/EC and 2009/.../EC. COM (2009) 207.

European Commission (2010) Proposal for a Directive .../.../EU of the European Parliament and of the Council on Deposit Guarantee Schemes [recast], COM (2010)368. 
Green Cowles, M., Caporaso, J. A., Risse-Kappen, T. (2001) Transforming Europe: Europeanization and Domestic Change, USA: Cornell University Press.

Hall, P. A., and Soskice, D. (eds) (2001) Varieties of Capitalism. The Institutional Foundations of Comparative Advantage, New York: Oxford University Press.

Harcourt, Alison (1998) 'EU Media Ownership Regulations: Conflict over Definition of Alternatives', Journal of Common Market Studies 36(3): 369-389.

Klüver, H, Braun, C. and Beyers, J. (2015) < THIS ISSUE: PUBLISHER TO ADD /UPDATE DETAILS AT PROOF>

Klüver, H., Mahoney, Ch., Opper, M. (2015) <THIS ISSUE: PUBLISHER TO ADD /UPDATE DETAILS AT PROOF>

Lijphart, A. (2012) Patterns of Democracy. Government Forms and Performance in ThirtySix Countries, New Haven: Yale University Press, $2^{\text {nd }}$ edition.

Majone, G. (1989) Evidence, Argument, \& Persuasion in the Policy Process. New Haven: Yale University Press.

Majone, G. (1996) Regulating Europe, London: Routledge.

Marks, G. (1993) 'Structural Policy and Multilevel Governance in the EC', in A. W. Cafruny and G.G. Rosenthal (eds), The State of the European Community, Vol 2: The Maastricht Debates and Beyond, Boulder Col: Harlow Longman, pp. 391-410.

Peterson, J. (2001) 'The Choice for EU Theorists: Establishing a Common Framework for Analysis', European Journal of Political Research 39: 289-318.

Ringe, N. (2005) 'Policy Preference Formation in Legislative Politics: Structures, Actors, and Focal Points', American Journal of Political Science 49(4): 731-745.

Scharpf, F. (1997) Games Real Actors Play. Boulder, CO: Westview Press.

Schattschneider, E. E. (1960) The Semi-Sovereign People, New York: Holt, Rinehart and Winston.

Schreier, M. (2012) Qualitative Content Analysis in Practice, Los Angeles: Sage.

Stone Sweet, A., Sandholtz, W., Fligstein, N. (2001) The Institutionalization of Europe, Oxford, UK: Oxford University Press.

Surel, Y. (2000) 'The Role of Cognitive and Normative Frames in Policy-Making', Journal of European Public Policy 7(4): 495-512. 


\section{Table 1 The definition of the independent variables}

\begin{tabular}{|c|c|}
\hline Concept & Variable definition \\
\hline \multicolumn{2}{|l|}{ Institutional context } \\
\hline EU level actors & $1=$ EU level actors, $0=$ Swedish actors \\
\hline EU member states & $\begin{array}{l}\text { Three dummy variables for German, British, and Dutch actors (reference } \\
\text { category: Swedish actors) }\end{array}$ \\
\hline \multicolumn{2}{|l|}{ Policy context } \\
\hline Policy area & $1=$ Environment, $0=$ Finance and Economy \\
\hline \multicolumn{2}{|l|}{ Strategic action } \\
\hline Interest group density & Number of actors vocal in a policy debate \\
\hline $\begin{array}{l}\text { Problem definition: } \\
\text { policy urgency }\end{array}$ & $\begin{array}{l}2=\text { arguments referring to expert evidence and the urgency of the proposed } \\
\text { measures, } 1=\text { arguments referring to expert evidence } \text { or the urgency of the } \\
\text { proposed measures, } 0=\text { no such arguments }\end{array}$ \\
\hline $\begin{array}{l}\text { Causal aspects: } \\
\text { constituency interests }\end{array}$ & $\begin{array}{l}2=\text { arguments referring to the interests of policy addressees and the EU } \\
\text { public, } 1=\text { arguments referring to the interests of policy addressees } \text { or the EU } \\
\text { public, } 0=\text { no such arguments }\end{array}$ \\
\hline $\begin{array}{l}\text { Moral aspects: } \\
\text { normative justification }\end{array}$ & $\begin{array}{l}2=\text { arguments referring to broad common goals and universal norms, } \\
1=\text { arguments referring to broad common goals } \text { or universal norms, } 0=\text { no } \\
\text { such arguments }\end{array}$ \\
\hline $\begin{array}{l}\text { Remedial aspects: costs } \\
\text { and benefits }\end{array}$ & $\begin{array}{l}2=\text { arguments referring to the distribution of costs and benefits and the social } \\
\text { benefits of the proposed measures, } 1=\text { arguments referring to the distribution } \\
\text { of costs and benefits or the social benefits of the proposed measures, } 0=\text { no } \\
\text { such arguments }\end{array}$ \\
\hline \multicolumn{2}{|l|}{ Control variables } \\
\hline Policy position & $\begin{array}{l}\text { Two dummy variables for a position in favour of the proposed policy } \\
\text { changes and for a position opposed to the proposed policy changes } \\
\text { (reference category: actor has no clear or neutral position) }\end{array}$ \\
\hline $\begin{array}{l}\text { Extent of perceived } \\
\text { policy change }\end{array}$ & $\begin{array}{l}1=\text { actor perceives major change or entirely new policy, } 0=\text { actor perceives } \\
\text { incremental or routine change }\end{array}$ \\
\hline Type of actor & $\begin{array}{l}\text { Four dummy variables for public interest groups, business interest groups, } \\
\text { firms, institutions (reference category: EU and national state actors) }\end{array}$ \\
\hline
\end{tabular}


Table 2 Essential frames in EU policymaking

\begin{tabular}{|c|c|c|c|c|c|}
\hline Frames & WEEE & RED & AIFM & DGS & Total \\
\hline \multicolumn{6}{|l|}{ Generic institutional frames } \\
\hline Implementation & 3 & 0 & 1 & 1 & 5 \\
\hline Regulation & 7 & 3 & 26 & 2 & 38 \\
\hline Harmonization & 5 & 11 & 18 & 29 & 63 \\
\hline $\begin{array}{l}\text { Administrative and economic } \\
\text { burdens }\end{array}$ & 9 & 4 & 9 & 1 & 23 \\
\hline Information and transparency & 0 & 3 & 1 & 3 & 7 \\
\hline \multicolumn{6}{|l|}{ Specific institutional frame } \\
\hline Mandatory targets & 0 & 24 & 0 & 0 & 24 \\
\hline \multicolumn{6}{|l|}{ Generic policy frames } \\
\hline Market integration & 2 & 0 & 4 & 5 & 11 \\
\hline Employment & 0 & 0 & 2 & 0 & 2 \\
\hline Consumer safety & 0 & 0 & 6 & 37 & 43 \\
\hline Health & 2 & 0 & 0 & 0 & 2 \\
\hline \multicolumn{6}{|l|}{ Specific policy frames } \\
\hline Financial market stability & 0 & 0 & 9 & 26 & 35 \\
\hline Environment & 16 & 23 & 0 & 0 & 39 \\
\hline Climate & 0 & 7 & 0 & 0 & 7 \\
\hline Energy & 0 & 16 & 0 & 0 & 16 \\
\hline Total & 47 & 91 & 76 & 104 & 316 \\
\hline
\end{tabular}


Table 3 Accounting for essential frames in EU policy debates: Poisson regressions

\begin{tabular}{|c|c|c|c|c|}
\hline & $\begin{array}{l}\text { Model } 1 \\
\text { Total number } \\
\text { of frames }\end{array}$ & $\begin{array}{l}\text { Model } 2 \\
\text { No. of generic } \\
\text { institutional frames }\end{array}$ & $\begin{array}{l}\text { Model } 3 \\
\text { No. of generic } \\
\text { policy frames }\end{array}$ & $\begin{array}{l}\text { Model } 4 \\
\text { No. of specific } \\
\text { policy frames }\end{array}$ \\
\hline \multicolumn{5}{|c|}{ Institutional and policy context } \\
\hline German actors & $\begin{array}{l}-0.465 * * \\
(0.215)\end{array}$ & $\begin{array}{l}-0.360 \\
(0.331)\end{array}$ & $\begin{array}{l}-0.759 \\
(0.512)\end{array}$ & $\begin{array}{l}-0.531 \\
(0.429)\end{array}$ \\
\hline Dutch actors & $\begin{array}{l}-0.121 \\
(0.106)\end{array}$ & $\begin{array}{l}0.021 \\
(0.159)\end{array}$ & $\begin{array}{l}-0.739 * * \\
(0.325)\end{array}$ & $\begin{array}{l}-0.001 \\
(0.200)\end{array}$ \\
\hline British actors & $\begin{array}{l}-0.132 * * \\
(0.056)\end{array}$ & $\begin{array}{l}-0.118 \\
(0.085)\end{array}$ & $\begin{array}{l}-0.271 * * \\
(0.138)\end{array}$ & $\begin{array}{l}-0.115 \\
(0.109)\end{array}$ \\
\hline EU level actors & $\begin{array}{l}-0.099 * * * \\
(0.029)\end{array}$ & $\begin{array}{l}-0.085^{*} \\
(0.044)\end{array}$ & $\begin{array}{l}-0.071 \\
(0.064)\end{array}$ & $\begin{array}{l}-0.123 * * \\
(0.058)\end{array}$ \\
\hline Policy area & $\begin{array}{l}-1.764 * * * \\
(0.487)\end{array}$ & $\begin{array}{l}0.304 \\
(0.731)\end{array}$ & $\begin{array}{l}-5.259 * * * \\
(1.28)\end{array}$ & $\begin{array}{l}-1.811^{*} \\
(0.992)\end{array}$ \\
\hline \multicolumn{5}{|l|}{ Strategic action } \\
\hline Interest group density & $\begin{array}{l}0.029 * * \\
(0.012)\end{array}$ & $\begin{array}{l}-0.038 * * \\
(0.019)\end{array}$ & $\begin{array}{l}0.068^{* *} \\
(0.032)\end{array}$ & $\begin{array}{l}0.053 * * \\
(0.025)\end{array}$ \\
\hline Problem definition & $\begin{array}{l}0.301 * * * \\
(0.095)\end{array}$ & $\begin{array}{l}0.393 * * * \\
(0.148)\end{array}$ & $\begin{array}{l}0.324 \\
(0.253)\end{array}$ & $\begin{array}{l}0.141 \\
(0.176)\end{array}$ \\
\hline Causal aspects & $\begin{array}{l}0.291 * * * \\
(0.090)\end{array}$ & $\begin{array}{l}0.184 \\
(0.139)\end{array}$ & $\begin{array}{l}0.462 * * \\
(0.212)\end{array}$ & $\begin{array}{l}0.380 * * \\
(0.165)\end{array}$ \\
\hline Moral aspects & $\begin{array}{l}0.316 * * * \\
(0.087)\end{array}$ & $\begin{array}{l}0.304 * * \\
(0.136)\end{array}$ & $\begin{array}{l}0.290 \\
(0.219)\end{array}$ & $\begin{array}{l}0.416^{* *} \\
(0.152)\end{array}$ \\
\hline Remedial aspects & $\begin{array}{l}0.267 * * * \\
(0.100)\end{array}$ & $\begin{array}{l}0.026 \\
(0.169)\end{array}$ & $\begin{array}{l}0.264 \\
(0.248)\end{array}$ & $\begin{array}{l}0.416^{* *} \\
(0.178)\end{array}$ \\
\hline Control variables & & & & \\
\hline $\begin{array}{l}\text { Policy position: } \\
\text { support of policy }\end{array}$ & $\begin{array}{l}-0.046 \\
(0.153)\end{array}$ & $\begin{array}{l}-0.096 \\
(0.234)\end{array}$ & $\begin{array}{l}-0.020 \\
(0.427)\end{array}$ & $\begin{array}{l}0.045 \\
(0.273)\end{array}$ \\
\hline $\begin{array}{l}\text { Policy position: } \\
\text { opposition to policy }\end{array}$ & $\begin{array}{l}-0.066 \\
(0.149)\end{array}$ & $\begin{array}{l}-0.133 \\
(0.222)\end{array}$ & $\begin{array}{l}0.448 \\
(0.344)\end{array}$ & $\begin{array}{l}-0.111 \\
(0.298)\end{array}$ \\
\hline $\begin{array}{l}\text { Actor type: } \\
\text { public interest group }\end{array}$ & $\begin{array}{l}0.157 \\
(0.238)\end{array}$ & $\begin{array}{l}-0.133 \\
(0.365)\end{array}$ & $\begin{array}{l}-0.653 \\
(0.601)\end{array}$ & $\begin{array}{l}-0.281 \\
(0.445)\end{array}$ \\
\hline $\begin{array}{l}\text { Actor type: } \\
\text { firm }\end{array}$ & $\begin{array}{l}-0.392 * \\
(0.223)\end{array}$ & $\begin{array}{l}-0.358 \\
(0.359)\end{array}$ & $\begin{array}{l}-0.338 \\
(0.553)\end{array}$ & $\begin{array}{l}-0.405 \\
(0.378)\end{array}$ \\
\hline $\begin{array}{l}\text { Actor type: } \\
\text { business interest group }\end{array}$ & $\begin{array}{l}-0.079 \\
(0.191)\end{array}$ & $\begin{array}{l}0.118 \\
(0.294)\end{array}$ & $\begin{array}{l}-0.453 \\
(0.472)\end{array}$ & $\begin{array}{l}-0.268 \\
(0.352)\end{array}$ \\
\hline $\begin{array}{l}\text { Actor type: } \\
\text { institution }\end{array}$ & $\begin{array}{l}-0.283 \\
(0.257)\end{array}$ & $\begin{array}{l}-0.470 \\
(0.444)\end{array}$ & $\begin{array}{l}0.961 \\
(0.826)\end{array}$ & $\begin{array}{l}-0.143 \\
(0.403)\end{array}$ \\
\hline Policy change & $\begin{array}{l}0.148 \\
(0.142)\end{array}$ & $\begin{array}{l}-0.027 \\
(0.220)\end{array}$ & $\begin{array}{l}-0.229 \\
(0.353)\end{array}$ & $\begin{array}{l}0.543 \\
(0.277)^{* *}\end{array}$ \\
\hline Constant & $\begin{array}{l}-1.494 * \\
(0.772)\end{array}$ & $\begin{array}{l}1.860^{*} \\
(1.128)\end{array}$ & $\begin{array}{l}-4.587 * * \\
(2.062)\end{array}$ & $\begin{array}{l}-4.801 * * * \\
(1.564)\end{array}$ \\
\hline $\mathrm{N}$ & 307 & 307 & 307 & 307 \\
\hline LL Intercept & -422.381 & -266.374 & -158.810 & -216.787 \\
\hline
\end{tabular}




$\begin{array}{lllll}\text { LL Full model } & -363.779 & -228.274 & -103.524 & -185.067 \\ \text { LR Chi }^{2}(17) & 117.205 & 76.200 & 110.573 & 63.440 \\ \mathrm{P} & 0.000 & 0.000 & 0.000 & 0.000 \\ \text { Pseudo }{ }^{2} & 0.138 & 0.143 & 0.348 & 0.146\end{array}$

Note: $*$ significant at $\mathrm{p}=0.1, * *$ sig. at $\mathrm{p}=0.05$ sig. at $\mathrm{p}=0.01$. 